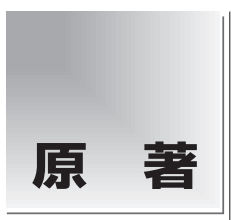

論文受付

2010年 9月24日

論文受理

2011 年 6 月28日

Code No. 251

\section{コンピュータ制御による冠動脈 CT 対応 動態評価用ファントムを用いた EMR とDSCT との比較検討}

\author{
大橋一也 ${ }^{1,2)}$ ・市川勝弘 ${ }^{2)}$ 東出 了$^{1,2)}$. 國友博史 ${ }^{1)}$ \\ 1 ) 名古屋市立大学病院中央放射線部 \\ 2)金沢大学大学院医学系研究科保健学専攻
}

\section{緒}

近年マルチスライス $\mathrm{CT}$ (multi slice computed tomography; MSCT)の多列化やガントリ回転速度の高 速化, 心電同期画像再構成法の向上によって心臓 CT の画質が向上し，その検査の需要が急速に増加して いる. 最近では冠動脈の描出のみならず, percutaneous coronary intervention $(\mathrm{PCI})$ 後の冠動脈ステント内腔の 評価や冠動脈狭窄のプラークの評価などのために, さらなる画質の向上が求められている，冠動脈 CT の 画質はモーションアーチファクトを低減するために 時間分解能が重要な要素であり，その時間分解能の 測定について，2000 年にTaguchi らが発表した時間
感度プロファイル (temporal sensitivity profile; TSP) を用いて, 秋野らが冠動脈 CT にも応用して報告して いる1,2).

最近の CT 装置は分割式心拍同期画像再構成法 (以下, electrocardiogram (ECG)-gated multi-segment reconstruction; EMR)により心位相の時間分解能を向 上させる機構が搭載され，メーカによってはマルチサ イクル再構成, マルチセク夕再構成, セグメント再構 成などと呼ばれている。 EMRはへリカルスキャンと ECG 信号のデータ収集を同時に行い, ハーフ再構成 に必要な投影データを複数のセグメントに分割し，そ のセグメントを複数の心拍データから収集することに

\title{
A Comparative Study of Electrocardiogram Multi-segment Reconstruction and Dual Source Computed Tomography Using a Computer Controlled Coronary Phantom
}

Kazuya Ohashi,, 2) Katsuhiro Ichikawa, ${ }^{2)}$ Ryo Higashide,, 2) and Hirosi Kunitomo ${ }^{1)}$

1 ) Central Department of Radiology, Nagoya City University Hospital

2) Graduate School of Medical Science, Kanazawa University

Received September 24,2010; Revision accepted June 28, 2011; Code No. 251

\section{Summary}

Currently, there are two main methods for improving temporal resolution of coronary computed tomography (CT): electrocardiogram-gated multi-segment reconstruction (EMR) and dual source scanning using dual source CT (DSCT). We developed a motion phantom system for image quality assessment of cardiac CT to evaluate these two methods. This phantom system was designed to move an object at arbitrary speeds during a desired phase range in cyclic motion. By using this system, we obtained coronary CT mode images for motion objects like coronary arteries. We investigated the difference in motion artifacts between EMR and the DSCT using a 3-mm-diameter acrylic rod resembling the coronary artery. EMR was evaluated using 16-row multi-slice CT (16MSCT). To evaluate the image quality, we examined the degree of motion artifacts by analyzing the profiles around the rod and the displacement of a peak pixel in the rod image. In the 16MSCT, remarkable increases of artifacts and displacement were caused by the EMR. In contrast, the DSCT presented excellent images with fewer artifacts. The results showed the validity of DSCT to improve true temporal resolution.

Key words: computed tomography (CT), temporal resolution, temporal sensitivity profile (TSP), coronary CT, dual source $C T$ (DSCT) 


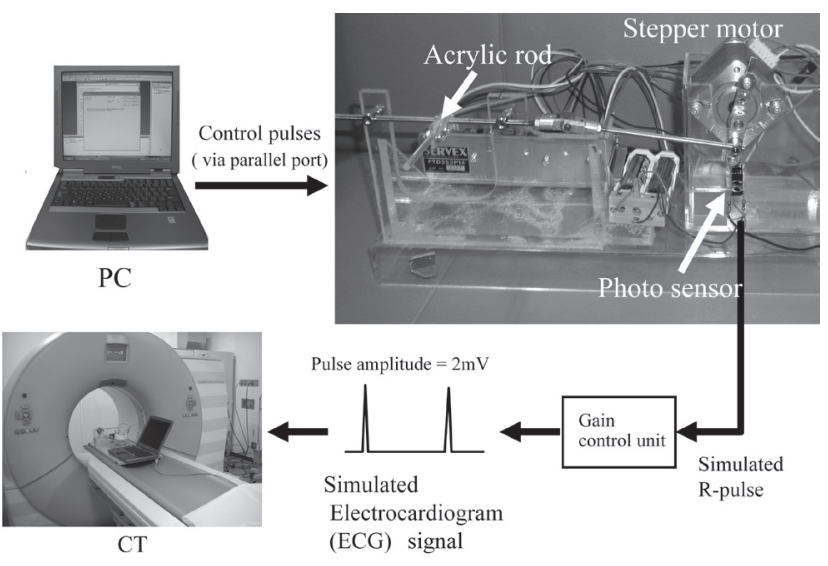

Fig. 1 Composition and the control method of the computer-controlled motion phantom.

よって時間分解能の向上が可能となっている。この EMRによる再構成で示される時間分解能は, 複数の 心拍から画像再構成に必要なすべてのデー夕を収集 するのに必要な時間ではなく，各心拍で使用される デー夕収集時間であり心位相に対する時間分解能(以 下，位相時間分解能)である. 位相時間分解能は，セ グメントが均等に分割される場合には，七グメントに 用いる一つの心拍に打ける収集時間を示す。複数の セグメント間で収集時間が異なる場合(不均等分割の 場合) は，均等分割より位相時間分解能は劣る ${ }^{3}$ 。こ の位相時間分解能は, ガントリ回転速度, ピッチファ クタと被検者の心拍数(heart rate; HR)によって複雑 に変化する2)。また, 最近登場した 2 管球 CT (dual source CT; DSCT) では, 2 組の X 線管と検出器が搭 載されている。この $\mathrm{X}$ 線管と検出器が 90 度ずらして 配置されている場合は，それぞれが 90 度回転するだ けでハーフ再構成に必要なデー夕を収集することが できる ${ }^{4)}$ ，そのためガントリ回転速度の $1 / 4$ の時間分 解能となる。 この場合の時間分解能は, 1 心拍のみの デー夕収集時間となり実時間分解能と一致する。この 論文で述べる実時間分解能とは，ハーフ再構成で用 いる 1 心拍のみのデー夕による画像の時間分解能を 表し，EMRにより複数の心拍からデータ収集をする ことで実時間の経過したデー夕を使用する位相時間 分解能と区別する目的で使用する.

EMR の評価として冠動脈の動きを模擬した心臓動 態ファントムによる研究が行われている5 そ ファントムの構造は風船様の袋を周期的に膨らます 構造であるため, 模擬した冠動脈はスライス位置に よって移動量が違うことから定量的な評価に使用す ることは困難である。一般に EMR では心臟の動きの 少ない位相をねらい, 1 心拍中の短い時間の投影デー 夕を複数心拍から収集するが，この位相期間内に冠 動脈が正確に停止している確証はなく, 特に高心拍

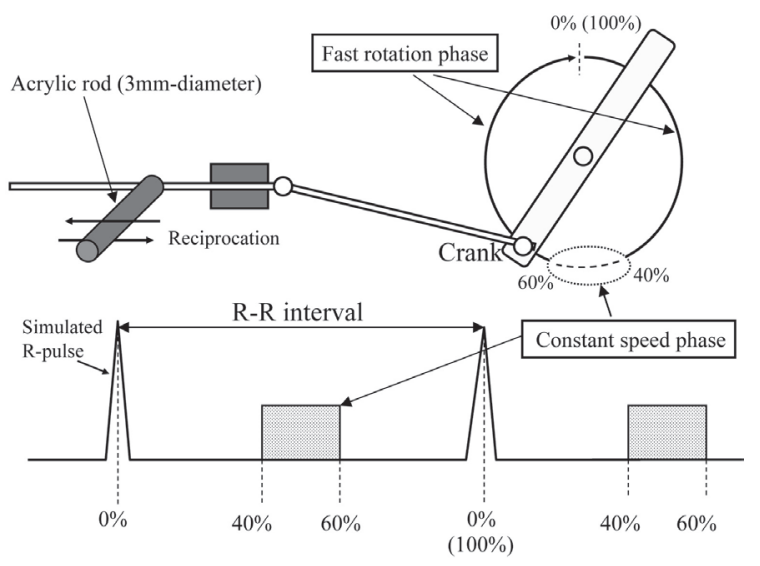

Fig. 2 Drive mechanism of acrylic bar phantom and speed control method in a cardiac phase.

においては，動きの少ない時間がごく短時間となるた め, EMRによる収集時間(位相)内で心血管が動いて いる状態での画像再構成を余儀なくされることが少 なくない．またハーフ再構成を複数のセグメントに複 雑に分割するため, 動きや位相の微妙に違うセグメ ントの合成となり，単に血管の移動速度だけにとどま らない影響が推測される。

よって, EMR を含めた冠動脈 CT においては, 心 周期に合わせての動きに対しての評価が必要であ り，動きの定量性と再現性を重視したファントムに よって, 基本的な解析が可能となると考えられる。 そ こで，本研究では，コンピュータ制御によって駆動す る動態ファントムを開発し，まず基本的な評価のため に，任意の心位相内を一定速度で移動させ，画像取 得を行った。そして, 位相時間分解能と実時間分解 能の評価に抢いてハーフ再構成とセグメント再構成 における動きの影響について検討した。

\section{1. 方 法}

\section{1-1 動態ファントムの作成}

$\mathrm{EMR}$ と DSCT の二つの心電同期再構成法を比較 するために，任意の心位相内を一定速度で移動する 動態ファントムを作成した。動態ファントムは，ス テッピングモータ(KT42KM06，3相，0.6 deg/step：日 本サーボ社製)と専用ドライバユニット (FTD3S3P14： 日本サーボ社製)を使用し，自作のリンク機構と組み 合わせて作成した(Fig. 1)。この動態ファントムは ノートパソコンのパラレルポートに接続されコン ピュータプログラムにより制御されたパルス信号によ りコントロールされる。用いたステッピングモータ は, 1 回転あたり 600 パルスで制御でき，小刻みな動 きから滑らかな定速移動まで自由な速度変化を設定 可能である. Fig. 2 に示したようにステッピングモー 夕の 1 回転を 1 心拍とし, 動きのある対象に対する評 
価を行うため $\mathrm{R}-\mathrm{R}$ 間隔の 40〜 60\%を一定速度で移 動するようにモー夕制御を行った。 心電同期再構成に 必要な ECG 信号は R 波のみで十分であるため, Fig. 1 に示したように，クランクの端に取り付けられ細い アルミ板がフォトマイクロセンサを通過することで発 生するパルスによって擬似的な $\mathrm{R}$ 波を形成した。 ファントムを駆動させて撮影する際に同時に発生する この擬似的な ECG 信号を CT に入力することでファ ントムの心電同期再構成が可能となる。心血管を模 擬するファントムの本体は造影された冠動脈を想定 して直径 $3 \mathrm{~mm}$ のアクリル棒を使用した。アクリル棒 の CT 值は造影血管とは異なり，さらに周囲は空気と したため, 実際の造影冠動脈とは周囲とのコントラス 卜に大きな違いがある。よって，本研究では，主に形 状再現性やアーチファクトの状況を検討することを主 眼とした。

\section{1-2 CT 装置}

CT 装置は16DAS(data acquisition system)MSCT のフィリップスメディカルシステム社製 IDT16 (16MSCT) と DSCT 方式の 64DAS MSCT, シーメン ス社製 SOMATOM Definition(DSCT)を使用した。 16MSCT とDSCT の回転速度はそれぞれ $0.42 \mathrm{~s} / \mathrm{rot}$ と $0.33 \mathrm{~s} / \operatorname{rot}$ であ. CT画像解析に ImageJ $(\mathrm{NIH}$; National Institute of Health) と, プログラム言語であ る Visual Basic 6.0(Microsoft 社製)を使用した。

\section{1-3 HR の設定}

HR は，低心拍領域の 60 beats per minute (bpm) と 高心拍領域の $86 \mathrm{bpm}$ とした. $60 \mathrm{bpm}$ は, 16MSCT において均等 2 分割となる $63 \mathrm{bpm}$ より劣る位相時間 分解能を持ち，不均等分割の影響も検討可能である と考え採用した。また $86 \mathrm{bpm}$ は，16MSCT で 3 均等 分割となり, その理論的位相時間分解能が, DSCT のそれとほぼ一致することから，EMRとDSCTの比 較を検討できることから選んだ。各 HRにおける理論 上の位相時間分解能と EMR の分割数を Table 1 に示 す9). $60 \mathrm{bpm}$ の位相時間分解能は, 2 分割 (105 ms) と ハーフ再構成 $(210 \mathrm{~ms})$ の間となる。 EMRにおいて は, HRによって, 位相時間分解能が複雑に変化する が，これらを細かく検討することは多くの実験を必要 とするために二つの HR に限定した.

\section{1-4 TSP の測定}

実際に今回の測定条件が目的とする時間分解能が 得られているか確認を行うために，時間分解能の測 定を行った。測定方法は市川らにより報告された方 法 ${ }^{10)}$ を使用し，金属球をガントリ内に高速で通過させ
Table 1 Theoretical phase temporal resolution at each heart rate for $16 \mathrm{MSCT}$ and DSCT

\begin{tabular}{lccc}
\hline \hline & $\begin{array}{c}\mathrm{HR} \\
(\mathrm{bpm})\end{array}$ & $\begin{array}{c}\text { Phase temporal } \\
\text { resolution: } T R_{\mathrm{p}}(\mathrm{ms})\end{array}$ & $\begin{array}{c}\text { Segment } \\
\text { number }\end{array}$ \\
\hline 16MSCT & 60 & $105<T R_{\mathrm{p}}<210$ & 2 \\
& 86 & 70 & 3 \\
DSCT & 60 & 83 & 1 \\
& 86 & 83 & 1 \\
& 86 & 42 & 2 \\
\hline
\end{tabular}

て，その再構成画像から TSP を得て解析した。この 方法にて心電同期再構成法の時間分解能を測定する 場合は，金属球の発射が 1 回であることから，ハー フ再構成法には適用可能である。しかし, EMRにお いても，均等分割であれば，分割された一つのセグ メントの TSP が得られるため, 精度がやや劣るもの の適用は不可能ではない。 また, 位相時間分解能の 測定においては，スライス間隔を時間間隔に変換する のではなく，同じスライス位置で $\mathrm{R}-\mathrm{R}$ 間隔における 位相を変化させて再構成を行い, 次式の位相 $P(\%)$ から位相時間 $T p$ に変換して, この位相時間に対して の TSP を得た。

$$
T p=\frac{H R}{60} \times \frac{p}{100}
$$

今回検討する低心拍領域の HR は $60 \mathrm{bpm}$ である が, 均等分割ではないため, その位相時間分解能の 実測はできない.よって，その HRに近い2均等分 割となる $63 \mathrm{bpm}$ を測定し, それより劣る位相時間分 解能であること想定し，後のファントム実験などの評 価に反映させた。撮影条件は 2 台の CT 装置ともに $120 \mathrm{kV}, 100 \mathrm{mAs} / \mathrm{slice}$, pitch factor $(\mathrm{PF})=0.2$, スライ ス 厚 $=1 \mathrm{~mm}, \mathrm{FOV}($ field of view $)=50 \mathrm{~mm}$ として, デイテクタ構成, 再構成フィルタ関数, については, $16 \mathrm{MSCT}$ では $16 \times 0.75 \mathrm{~mm}, \mathrm{CB}$ に, DSCT では $32 \times$ $0.6 \mathrm{~mm}, \mathrm{~B} 26$ にそれぞれ設定した。再構成フィル夕 関数は, 2 機種ともメーカ推奨の心臓 CT 用である. また，それぞれの体幹部用の直径 $32 \mathrm{~cm}$ のファントム における線量值(volume CT dose index; CTDI $_{\mathrm{vol}}$ ), 16MSCT が 33.50 mGy，DSCT が 28.49 mGy であった.

\section{1-5 ファントム撮影}

開発した動態ファントムを用いて, HRの $60 \mathrm{bpm}$ と $86 \mathrm{bpm}$ について，心位相の 40〜60\%の間のアクリ ル棒の移動速度を $3,5,10,15,20 \mathrm{~mm} / \mathrm{s}$ に設定し スキャンした。撮影条件はTSPの撮影条件と同じと した。 また，予備実験にて16MSCTの 86 bpmにつ 


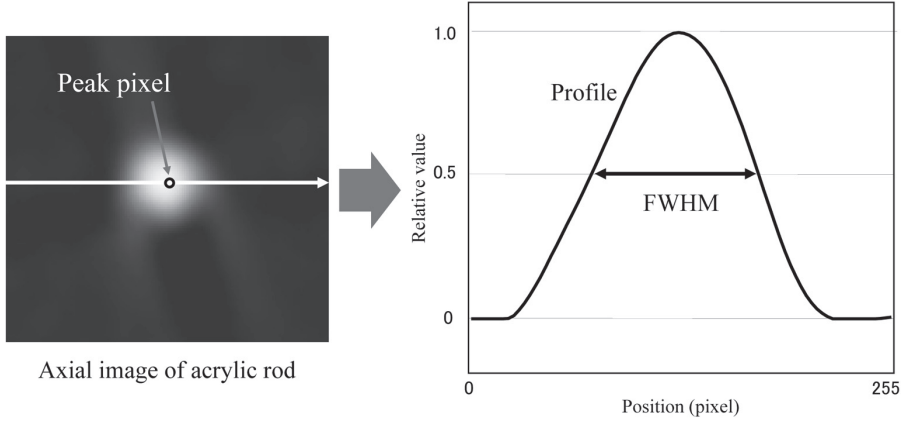

Fig. 3 Method of artifact analysis for images of the acrylic bar phantom.

Profiles across the center of phantom at angles of 0-179 degrees were obtained, and their full widths at half maximum were calculated.

いては，スライス位置によってモーションアーチファ クトの多い画像が出現し，3均等分割用のデータの不 足により, 不均等な 2 分割に切り替わる状況が生じ ていることが懸念されたため, $\mathrm{PF}=0.16$ の測定を追加 した. DSCTでは, 86 bpm において 2 分割再構成の 適用も可能であったため, その測定も行った.

ファントムの配置は心臓の中心付近での測定を模 擬しガントリ回転中心より $50 \mathrm{~mm}$ 左側にアクリル棒 が $x$ 軸方向に移動するようにセットした。アクリル 棒が長さ約 $40 \mathrm{~mm}$ であるため, 先端部分を除いた $35 \mathrm{~mm}$ の範囲で画像再構成を行った。

\section{1-6 ファントム画像の解析}

画像からのアーチファクト解析の方法を以下に述 ベる。アクリル棒は，動きによって単なるボケを呈す るのではなく，動きによるアーチファクトを生じる。 よってアクリル棒のボケを周波数解析する方法は適 切ではないと考えた。 そこでわれわれは，管状のファ ントムの正確な横断像は円径の画像を呈し, その中 心を通るプロファイルはすべての角度において一定 の形状を呈するべきであるという性質を利用し，アク リル棒の横断像のプロファイルを全方向にとり, その 変動を評価する以下のような方法を用いた。

自作動態ファントムを使用して得られたそれぞれの ファントム画像に対して, アクリル部分の CT 值が最 大になるピクセルを中心にプロファイルデータを取得 し, これの full width at half maximum(FWHM)を測 定した(Fig. 3). 本来ならばアクリル棒は均一な CT 值になることが理想的な状態であるが，空気中での 直径 $3 \mathrm{~mm}$ アクリル棒はFig. 3 に示したような山なり のプロファイルとなり, 静止状態において正確に最大 の CT 值が中心に現れるためにピーク CT 值をアクリ ル棒の中心として評価を行った。次に, プロファイル の方向を 1 度ずつ回転させて 180 本のプロファイル
のFWHMを平均した(平均 FWHM)。得られた FWHM がどの程度変動しているかを評価するために 180 本のプロファイルの FWHM の標準偏差(FWHM 変動)を求めて比較した。 モーションアーチファクト はスライス位置によって変化するために，1 mm 間隔 の 35 スライスの画像を使い, さらにこれを 5 回のス キャン分のすべてについて平均化した，DSCTにおい ては, $60 \mathrm{bpm}$ と $86 \mathrm{bpm}$ のハーフ再構成は実時間分 解能が同じであるため結果が等しくなるので, $60 \mathrm{bpm}$ のみについて測定した。

実際の冠動脈 CT では, axial 像から再構成した multi-planar reconstruction(MPR) 画像から狭窄率を 測定することがあるが，アーチファクトがどのように 影響を及ぼすかを評価する目的で，各条件における FWHM の最大偏差を求めて比較した。

ファントム移動速度が速い場合に16MSCTにおい て axial 像のピーク CT 值を示すピクセル (ピークピク セル)の $x$ 座標が変動したため, ファントム移動速度 $20 \mathrm{~mm} / \mathrm{s}$ における $16 \mathrm{MSCT} の 60 \mathrm{bpm}, 86 \mathrm{bpm}$, DSCT の 86 bpm についてピークピクセルの $x$ 座標の 位置変動を測定した。

以上のような, 定量的解析に加え, アクリル棒の軸 に沿った MPR 画像を再構成し視覚的に比較した。

\section{2. 結 果}

\section{2-1 時間分解能}

Fig. 4 にTSP の測定結果, Table 2 にTSP から求 めた FWHM による時間分解能を示す. DSCT の時間 分解能は理論值に等しい $83 \mathrm{~ms}$ であった. 16MSCT の $63 \mathrm{bpm}$ は, $110 \mathrm{~ms}$ となり理論值に近い值が得ら れた。 また $16 \mathrm{MSCT} の 86 \mathrm{bpm}$ では，一部のスライス 位置では $75 \mathrm{~ms}$ よ大きい $120 \mathrm{~ms}$ となり, 16MSCT の $63 \mathrm{bpm} よ り$ 長い時間分解能となり不均等 2 分割が 混在することが判明した. 


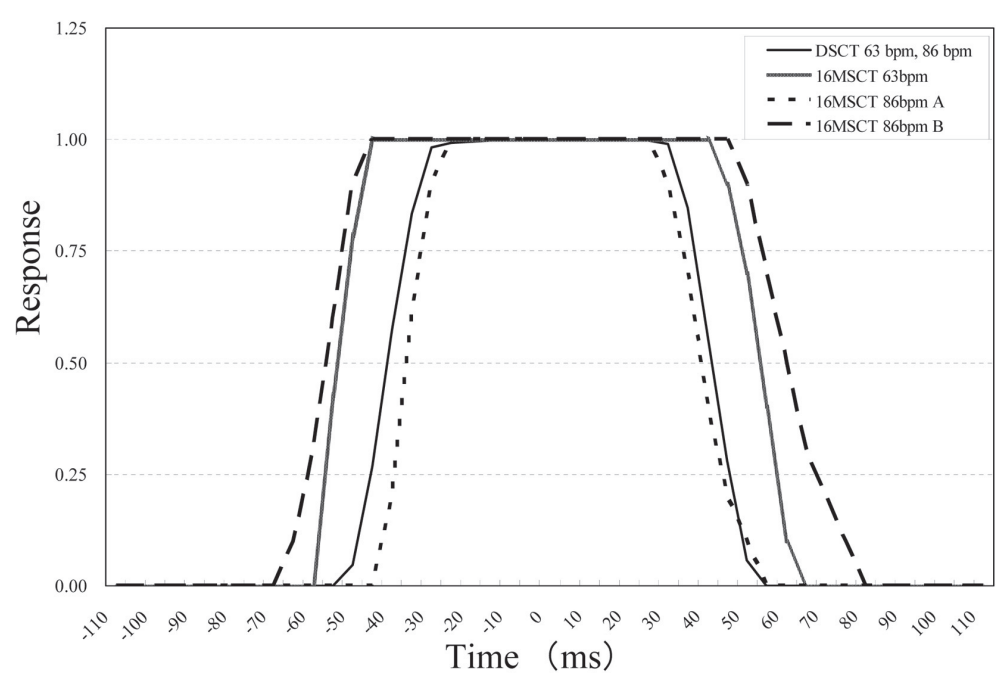

Table 2 Measured FWHMs of TSP and corresponding segment numbers

\begin{tabular}{llcc}
\hline \hline & $\begin{array}{c}\text { HR } \\
(\mathrm{bpm})\end{array}$ & $\begin{array}{c}\text { FWHM of } \\
\text { TSP (ms) }\end{array}$ & $\begin{array}{c}\text { Segment } \\
\text { number }\end{array}$ \\
\hline 16MSCT & 63 & 110 & 2 \\
& 86 & 75 & 3 \\
& 86 & 120 & 2 \\
DSCT & 63,86 & 83 & 1 \\
\hline
\end{tabular}

Fig. 4 Measured TSPs.

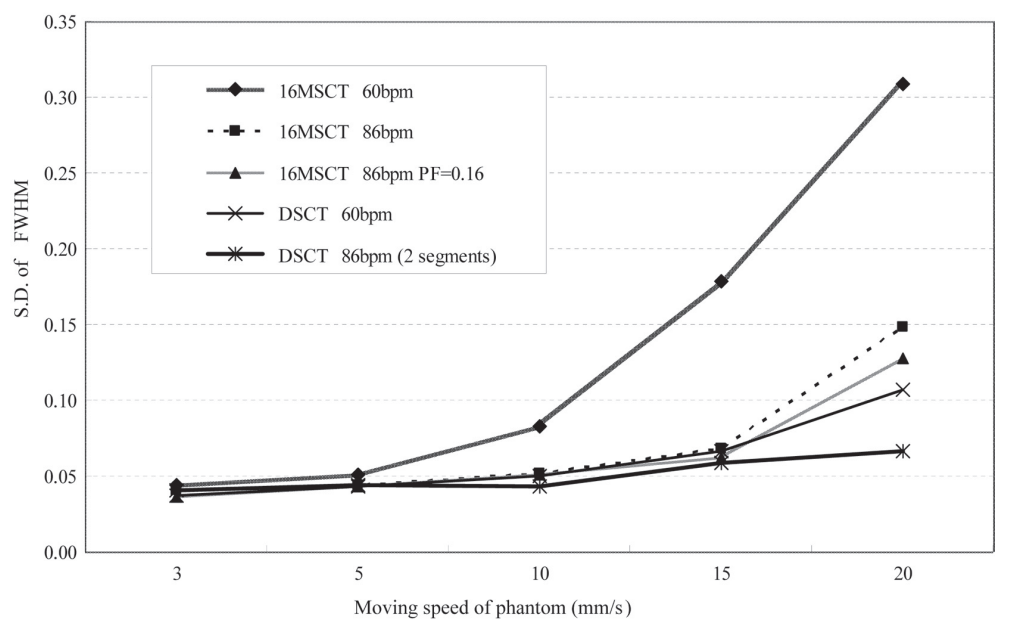

Fig. 5 Relationship between phantom speed and FWHM fluctuation of phantom profiles for 16MSCT (EMR) and DSCT.

Table 3 Maximum deviation of the FWHM of phantom profiles for $20 \mathrm{~mm} / \mathrm{s}$

\begin{tabular}{llc}
\hline \hline & HR $(\mathrm{bpm})$ & Maximum deviation $(\mathrm{mm})$ \\
\hline \multirow{2}{*}{ 16MSCT } & 60 & 0.356 \\
& 86 & 0.078 \\
& $86(\mathrm{PF}=0.16)$ & 0.068 \\
DSCT & 60 & 0.058 \\
& $86(2$ segments $)$ & 0.034 \\
\hline
\end{tabular}

\section{2-2 ファントム画像の解析}

Fig. 5 に 35 スライスのファントム画像を 5 回スキャ ンしたものを平均した FWHM 変動の結果を示す.

ファントム移動速度 $3 \mathrm{~mm} / \mathrm{s}$ ではどの撮影パラメータで も変動は少なく，差がみられなかった。 $10 \mathrm{~mm} / \mathrm{s}$ では $16 \mathrm{MSCT}$ の $60 \mathrm{bpm}$ で変動が大きくなり, $20 \mathrm{~mm} / \mathrm{s}$ では 16MSCT の $60 \mathrm{bpm}, 16 \mathrm{MSCT}$ の 86 bpm, 16MSCT の $86 \mathrm{bpm}(\mathrm{PF}=0.16), \operatorname{DSCT} の 60 \mathrm{bpm}, \operatorname{DSCT} の 2$ 分
割再構成 86 bpm の順で変動が大きくなった. 86 bpm の 16MSCT と DSCT との比較では，16MSCT がやや 時間分解能が高いにもかかわらず，ファントムの移動 速度が $20 \mathrm{~mm} / \mathrm{s}$ と速くなると FWHM 変動が大きくな り，アーチファクトが多くなることが示された。

Table 3 は, ファントムの移動速度が $20 \mathrm{~mm} / \mathrm{s}$ の各 HR における FWHM の最大偏差である.16MSCT の $60 \mathrm{bpm}$ が最も FWHM の最大偏差が大きく 16MSCT 

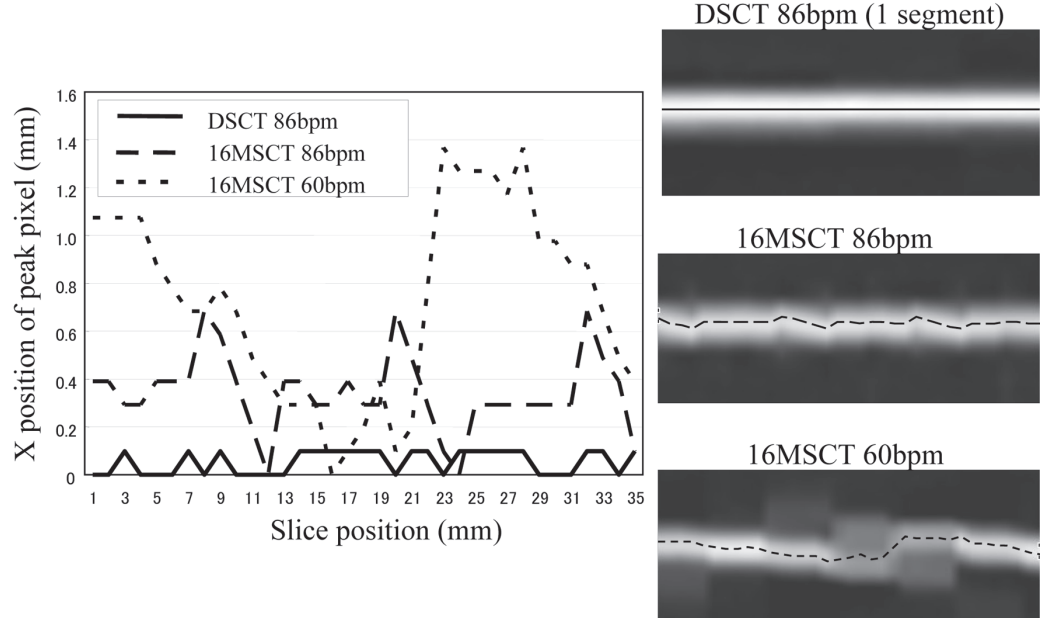

Fig. 6 Comparison of peak pixel displacements for phantom movement speeds of $20 \mathrm{~mm} / \mathrm{s}$.

Table 4 Standard deviations of displacements of peak pixels for $20 \mathrm{~mm} / \mathrm{s}$

\begin{tabular}{lcc}
\hline \hline & Heart rate $(\mathrm{bpm})$ & S.D. of x-position $(\mathrm{mm})$ \\
\hline \multirow{2}{*}{ 16MSCT } & 60 & 0.40 \\
& 86 & 0.16 \\
DSCT (1 segment) & 86 & 0.05 \\
\hline
\end{tabular}

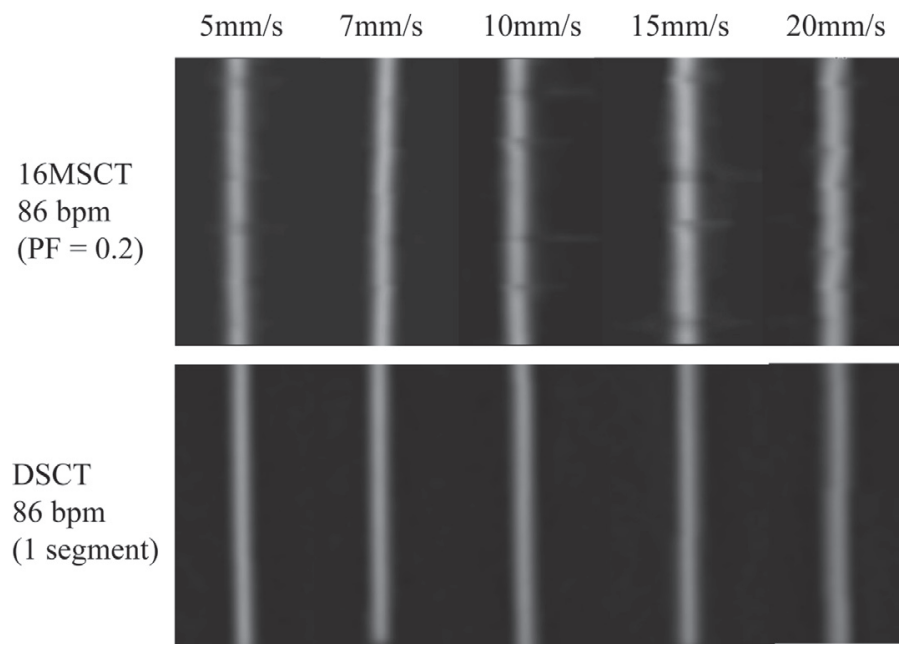

Fig. 7 Comparison of MPR images of $86 \mathrm{bpm}$ for respective phantom speeds.

の $60 \mathrm{bpm}, 16 \mathrm{MSCT} の 86 \mathrm{bpm}, 16 \mathrm{MSCT}$ の $86 \mathrm{bpm}$ $(\mathrm{PF}=0.16), \mathrm{DSCT} の 60 \mathrm{bpm}, \mathrm{DSCT} の 2$ 分割再構成 86 bpm の順で FWHM の最大偏差が大きくなった.

Fig. 6 にファントム移動速度 $20 \mathrm{~mm} / \mathrm{s}$ におけるピー クピクセルの $x$ 方向位置の変化と MPR 像を示す.

ファントムは $x$ 方向に移動する設計であることから $y$ 方向の変動はなかったが, 16MSCTにおいてはスラ イス位置が体軸方向位置によって $x$ 方向に蛇行する ように変動する結果となった。 35 スライスのピークピ クセルの $x$ 方向位置の標準偏差を Table 4 に示す.
DSCT の 86 bpm は $0.05 \mathrm{~mm}, 16 \mathrm{MSCT}$ の $60 \mathrm{bpm}$ と $86 \mathrm{bpm}$ では $0.4 \mathrm{~mm}, 0.16 \mathrm{~mm}$ となり, 16MSCT は位 置の変動が顕著に大きくなった。

\section{2-3 MPR 画像の比較}

Fig. 7 に $86 \mathrm{bpm}$ におけるファントム移動速度の変 化による MPR 像の変化を示す。16MSCTでは移動 速度が速くなるにつれて蛇行した MPR 像となった が，DSCTでは蛇行はみられなかった，Fig. 8 に 16MSCT におけるファントム移動速度 $20 \mathrm{~mm} / \mathrm{s}$ の HR 

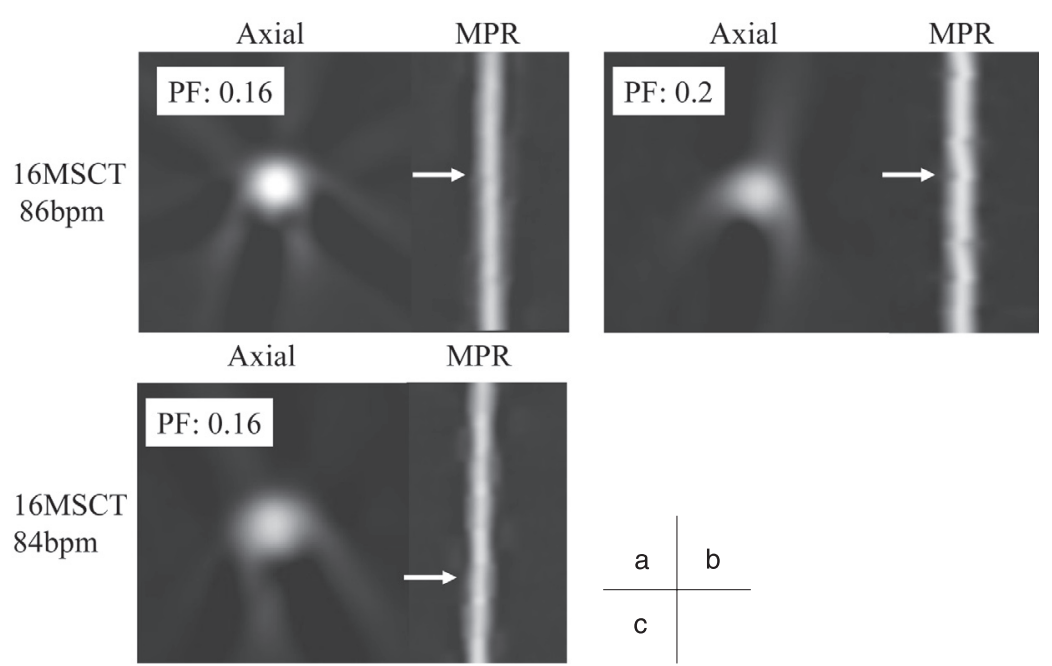

Fig. 8 Axial and MPR images for the phantom speed of $20 \mathrm{~mm} / \mathrm{s}$ for $16 \mathrm{MSCT}$

(a) 86 bpm, $P F=0.16$, (b) 86 bpm, $P F=0.2$, (c) 84 bpm, $P F=0.16$
および PFを変化させたaxial 像と MPR 像を示す。

$86 \mathrm{bpm}(\mathrm{PF}=0.16)$ は, $86 \mathrm{bpm}(\mathrm{PF}=0.2)$ よりもアーチファ クトが減少したが, $84 \mathrm{bpm}(\mathrm{PF}=0.16)$ ではアーチファク トが多い画像となった．Fig. 9 にDSCTの 86 bpm と 2 分割再構成の $86 \mathrm{bpm} の$ axial 像とMPR 像を示 す. 2 分割再構成の 86 bpm はアーチファクトが少な い画像となった

\section{3. 考 察}

ハーフ再構成の時間分解能の表現については，実 際に使用したデー夕量をそのまま使用するもの(180 度 + ファン角度分) と, 八ーフ再構成に打ける重み関数 を考慮してガントリ回転速度の半分(180 度分)を使用 するものの, 装置によって 2 種類が混在している ${ }^{11)}$.

今回, 時間分解能の理論值と回転中心部分の TSP よ り求められた FWHMによる時間分解能は近い值が得 られたことから，測定したDSCTによるハーフ再構成 はガントリ回転速度の 1/4(90 度)のデー夕を使用して 再構成を行っていることが明らかとなった。また，

EMRによるTSP 測定においても金属球の発射が 1 回であることから，分割された一つのセグメントに関 して時間分解能の測定が可能であった.

Axial 像の FWHM 変動に関してはファントム移動 速度 $15 \mathrm{~mm} / \mathrm{s}$ までは位相時間分解能が同等であれ ば，セグメント再構成とハーフ再構成はほぼ等しい結 果となり，アーチファクトの程度もほぼ等しくなるこ とが示された。しかし $20 \mathrm{~mm} / \mathrm{s}$ になると16MSCT は アーチファクトが多くなりファントムの形状を正確に 表すことができなかったままた，ピークピクセルの位 置からみたファントムの変位も同様に16MSCT にお いて大きな変動が観察された，EMR を用いることに

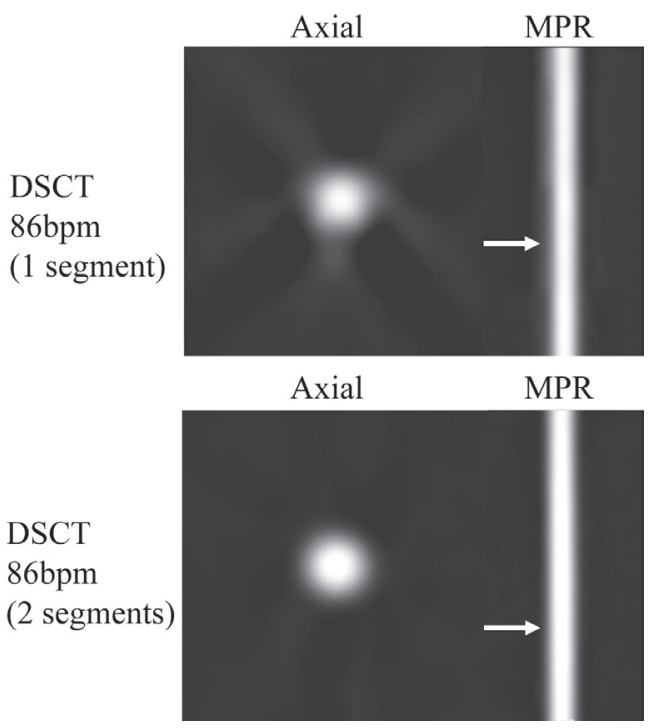

Fig. 9 Axial and MPR images for 20 $\mathrm{mm} / \mathrm{s}, 86 \mathrm{bpm}$ for DSCT. (a) 86 bpm, 1 segment, (b) 86 bpm, 2 segments
よって位相時間分解能が高くなれば，それに応じて モーションアーチファクトが少なくなるものと思われ たが，実際には移動速度が速くなるとアーチファクト が増加するだけではなく, 位置の変位も顕著となっ た、本装置は，正確な周期でファントムが移動するた め, 位相時間分解能が実時間分解能と実質的に同じ であるならば, EMRを用いることで動きのアーチ ファクトを抑制可能である。しかし，実際は，EMR を用いた再構成では，顕著なアーチファクトが現れ， ハーフ再構成との大きな違いが示された。この原因と して，位置によるEMRの分割数の変化と，分割した 各セグメントにおける細かな位相変動が推測され た. DSCT の $86 \mathrm{bpm}$ (実時間分解能： $83 \mathrm{~ms}$ ) は, EMRによらないため, ファントムは指定した位相に 対して常に同じ位置でスキャンされ，結果的にアーチ ファクトの少ない画像となっていることからも，その 推測を裏付けられる.

モーションアーチファクトが多くなると, Table 3 に 示すようにプロファイルの FWHM の最大偏差も顕著 に増加することが示された。これらは，冠動脈 CT 血 管径計測に扔ける精度への指標とも捉えられる。 ま た, Fig. 7 の 16MSCT の PF=0.2 の MPR 画像におい てところどころにみられるスパイク様の画像変化は, 1-5 で述べた 3 均等分割のデータ不足により生じた分 割数の変化(局所的な 2 分割への変更)による影響で ある。このように, アーチファクトの程度の違うスラ イスが混在することは, 狭窄病変としての誤診にもつ ながりかねないリスクが懸念された．この分割数の変 化を抑えるためにファントム移動速度 $20 \mathrm{~mm} / \mathrm{s}$ にお 
いて $\mathrm{PF}=0.16$ とした場合にはアーチファクトが抑制さ れた。しかし，心拍は常に一定とは限らないため,

Fig. 8 に示すようにHR が $84 \mathrm{bpm}$ になった場合には セグメント再構成が不均等分割となりアーチファクト が増加して axial 像も MPR 像も正確な形状を再現で きなくなる。これらのことからも位相時間分解能と実 時間分解能では同じ時間分解能であっても得られる 画像には大きな違いがある。よって, EMRに頼らな い実時間の時間分解能を高めることが不可欠である ことが示され, DSCT により実時間分解能を高めた上 でのハーフ再構成の有効性が示された.

今回用いた $16 \mathrm{MSCT}$ に対して, 現在の心臓 CT の 主流は64DASの MSCT となりつつある。しかし, EMR を用いる点では, 本研究の結果で問題となった スライス位置によるEMRの分割数の変化と, 不均等 分割による位相時間分解能の低下によるアーチファク
トの影響は同じである。ただし，64DASによるスキャ ン速度の向上を利用して，PFを低下させた場合に は，若干改善されると考えられる。

\section{4. 結 語}

EMR と DSCT の二つの心電同期再構成法の比較 を,コンピュータ制御によって周期的に任意の速度で 可動させることを可能とする自作の動態ファントムを 使用して画像の評価を行った。その結果, EMR は位 相時間分解能を高くすることでモーションアーチファ クトの抑制には有効な手段であるが，位相時間分解 能と実時間分解能の比較では同等の時間分解能で あっても EMR は PF や HR によって複雑に変化する アーチファクトが確認され，実時間分解能を向上でき るDSCT の有効性が示された。

\section{参考文献}

1) Taguchi K. High temporal resolution for multislice helical computed tomography. Med Phys 2000; 27(5): 861-872.

2) 秋野成臣, 辻岡勝美, 安野泰史, 他. マルチスライス CT を用いた分割式心拍同期画像再構成法に打ける時間分解 能評価. 日放技学誌 2005; 61(3): 409-418.

3) Kachelriess M, Ulzheimer S, Kalender WA. ECG-correlated image reconstruction from subsecond multi-slice spiral CT scans of the heart. Med Phys 2000; 27(8): 1881-1902.

4) 伊藤俊英, 大谷カタリーナ. Dual-Source Computed Tomography の開発. 医用画像情報会誌 2007; 24(2): 30-43.

5）沈雲, 佐々木公祐, 岡野善幸, 他. 高心拍領域に扮 ける MDCT の心臓イメージングの画質に関する評価. 日 放技学誌 2005; 61(4): 506-513.

6) 沈雲, 堀内哲也, 木村文子, 他. 心拍動によるモー
ションアーチファクト軽減のための高時間分解能再構成ア ルゴリズム。日放技学誌 1998; 54(11): 1287-1294.

7) 山本修司, 濱田星紀, 高堀一成, 他. ハーフセコンドマル チスライスCTによる retrospective ECG-gating 法の性能 評価. 日放技学誌 2002; 58(1): 94-100.

8) Flohr TG, McCollough CH, Bruder H, et al. First performance evaluation of a dual-source CT (DSCT) system. Eur Radiol 2006; 16(2): 256-268.

9）山下康行。心臓 CT をはじめよう! 心臓 CT の基礎と臨床 の実際. Rad Fan 2004;2(1)

10）市川勝弘, 高田忠徳, 原 孝則, 他. CT に扔ける時間分 解能の新しい測定法. 日放技学誌 2008; 64(9): 1172-1176.

11）木原康樹, 栗林幸夫. CT 冠動脈造影実践学. 中外医学 社, 東京, 2010: 13.

Fig. 1 自作動態ファントムの構成と制御方法

Fig. 2 アクリル棒ファントム駆動機構と心位相に扔けるスピードコントロール

Fig. 3 アクリル棒ファントムのモーションアーチファクト解析方法 ファントム画像に対して, CT 值が最大になるピクセルを中心にしてプロファイルデータを $0^{\circ}$ から $179^{\circ}$ 取得し FWHM を計 測する.

Fig. 4 測定されたTSP

Fig. 5 ファントム移動速度と, $16 \mathrm{MSCT}(\mathrm{EMR})$ と DSCT との FWHM 変動の関係

Fig. 6 ファントム移動速度 $20 \mathrm{~mm} / \mathrm{s}$ におけるピークピクセルの変位の比較

Fig. 786 bpm に打けるファントム移動速度の変化による MPR 像の比較

Fig. 8 ファントム移動速度 $20 \mathrm{~mm} / \mathrm{s}$ における 16MSCT の MPR 像と axial 像

(a) $86 \mathrm{bpm}, \quad \mathrm{PF}=0.16$, (b) $86 \mathrm{bpm}, \quad \mathrm{PF}=0.2$, (c) $84 \mathrm{bpm}, \quad \mathrm{PF}=0.16$

Fig. 9 ファントム移動速度 $20 \mathrm{~mm} / \mathrm{s}$ に执ける DSCT の MPR 像と axial 像 (a) 86 bpm, 1 segment, (b) 86 bpm, 2 segments

Table 1 16MSCT と DSCT の各心拍数における理論的位相時間分解能

Table 2 測定されたTSP の FWHM とセグメント分割数

Table 3 ファントム移動速度 $20 \mathrm{~mm} / \mathrm{s}$ における FWHM の最大偏差

Table 4 ファントム移動速度 $20 \mathrm{~mm} / \mathrm{s}$ に扔けるピークピクセルの変位の標準偏差 